\title{
ONLINE ENGLISH SHADOW EDUCATION: EFL LEARNERS' PERSPECTIVE
}

\author{
Elgie Septiya Lasnumanda ${ }^{1}$, Fatin Nadifa Tarigan ${ }^{2}$ \\ ${ }^{1}$ Universitas Negeri Malang \\ ${ }^{2}$ Universitas Pembinaan Masyarakat Indonesia \\ fatinnadifa@yahoo.com
}

\begin{abstract}
A number of shadow educations (private supplementary tutoring) of English have emerged in Indonesia regarding the fulfillment of the variety of students' needs in learning English that is not fully accommodated in conventional schooling. Apparently, the services provided in shadow educations have been transferred in online setting due to the rapid advancement of technology. This research aims at observing the EFL learners' perspective on online English shadow education. With a descriptive qualitative design, the subjects were involving $28 \mathrm{EFL}$ learners experiencing English shadow education in KII online English course. The data were collected from a questionnaire developed in closed- and open-ended formats. This research reports the result of a survey research on EFL learners' perspective on online English shadow educations that the EFL learners' participation were not only led by the same reasons of the conventional one but the practicality also contributes on it and challenges faced by the learners were revealed as well. Technical issues such as bad internet connection and limited interaction between the tutors and the learners were the major case in online English shadow education. Moreover, EFL learners also admitted that they were suffered from self-regulation learning strategy and it relates to teaching pedagogy as well. These results have implications for EFL practitioners aiming at better understanding current EFL learners.
\end{abstract}

Keywords: English, online shadow education, language learning

\section{INTRODUCTION}

English is established in Indonesia as foreign language (EFL) and has been created an environment for its adjustment on the current curriculum. Based on the application of the 2013 curriculum, English lesson is commonly taught in Indonesian secondary school for about four academic hours a week. Meanwhile, as a general course in the university level, English is only taught for 2 to 5 credit units per four years learning at the university. The time allotment for English Language Teaching (ELT) in Indonesian formal education is insufficient to accommodate the needs of Indonesian EFL learners. However, the expectation of proficiency in English is so high for learners in order to meet the demand of world society which requires English as an international language in relation to marketing, job seeking, immigration purposes, scholarship application, admission for higher education, publication and access to Information and Technology in Industrial Revolution 4,0.

Based on the fact, most Indonesian university students were confronted with lack of English communication skills. Most of them were failed in mastering language productive skills especially on speaking skill. In addition, based on interviewing three university students who took 
English online courses, it was obtained that they felt that their last formal education, school and university had given small contribution to improve their English communication skill. Consequently, they are actively looking for assistance in learning English to fulfill their needs. It has been depicted as a youth culture, school culture, and parent culture of depending on private tutoring for exams and educational success (Bray \& Lykins, 2012). The phenomenon then contributes to the wide-spread shadow education of English in Indonesia.

Interestingly, due to rapid advancement of technology in all aspects of today's life, shadow education has been transferred into online setting. Online learning is believed to provide unique advantages in the learning process (Shopova, 2014). Formerly, English was firstly taught in traditional learning in which students learn only from their teachers. Therefore, they cannot obtain any learning information immediately. However, the existence of internet nowadays makes the learning activities have started to shift from conventional classroom settings to online learning environments. Thus, many services of English shadow education emerge in Indonesia.

Learners having participation in shadow education are believed to seek academic assistance in learning due to the reasons emphasized in the following studies. Alotaibi (2014) examined the views of Saudi secondary school students and their parents on the causes of private tutoring in English by interviewing them in a separate group. He points out that difficulty of the English language, weak teacher performance, social pressure, variability in student comprehension levels at school, weak English foundation in previous school years, repeated student absence from school, large classes, and English heavy teaching loads are determined as the causes of private tutoring in English. Further, Dwita et al. (2018) surveyed 433 participants of private tutoring at 13 cities and municipalities in West Sumatra. The study conveys that there are five factors comprising secondary school students' participation in shadow education. Those factors are individual (a combination of personal ambitions, desires, and academic achievement), family (a combination of parents' desires, suggestions and busyness), school (a combination of teachers' aspect and suggestions), private tutorial (a combination of learning process in the private tutoring, promotion, and instructors' aspects), and peer factors. Then, findings in William's research (2018) revealed that students registering on private tutoring services are due to their academic achievements and/or problem, their parents-related decision, and their view on the usefulness of private tutoring services. He also suggested that schools and policy makers may start to study these phenomena thoroughly and produce reliable policies to improve students' experience in regular schooling.

Concerning the reasons of learners' participation in shadow education, the implications of shadow education on mainstream education system are found. Wang and Bray (2016) interviewed 47 teachers from 12 secondary schools and found their ambivalent views towards private tutoring. While the teachers regarded tutoring as a supplement to teaching, they also criticized tutoring for distorting the purpose of education which is supposed to promote whole-person development. Nam and Chan (2019) observed the relationship between schools and tutoring of English subject. It was found that both schooling and tutoring are involved in working mutually to cover each other's weaknesses as students' individuality and an abundance of resources can be used to improve their English. Despite what has just been said, Nam and Chan added that students' weighing more on tutoring might cause them to have conflicts with their teachers, thus damaging their relationship in the process. Therefore, policymakers are suggested to reflect on what purpose 
language education is.

Despite the contradiction between shadow education and mainstream education, learners seem to lay on shadow education. Since post-secondary education becomes within reach, more students seek private tutoring to better equip themselves to compete in the admission test. They are more motivated to invest their time and energy in private tutoring to maximize their chance to be admitted to prestigious universities (Yung \& Bray, 2017). Chan's study (2019) indicates that students' needs and beliefs in English learning play key roles in determining their receipt of English tutoring and suggests that teachers may need better understanding of their students' needs so as to design suitable pedagogies.

Based on these issues, this research aims at observing Indonesian EFL learners' perspective on online English shadow education. The research is expected to contribute especially to online English courses and English tutors in developing English online tutoring in Indonesia by knowing the learners' perspective.

\section{REVIEW OF LITERATURE Shadow Education}

It is common phenomenon that private supplementary tutoring is considered as shadow education (Bray \& Silova, 2006). In addition, shadow education is known as a service of private supplementary tutoring which exists simultaneously with mainstream schooling and 'shadow' the regular school system (Bray, 2014) and it has an additional fee to be operated (Mahmud \& Kenayathulla, 2017). Hence, the term 'shadow education' refers to private education by informal education institutions or tutoring informally by individual teacher.

\section{Learning English in Online Setting}

The rise of technology might be supported by the vivid preference of EFL learners to learn English in online setting. Most English learners think that using the Internet to learn English is more convenient than using traditional methods; and that most adult English learners think that using the Internet to learn English is more helpful than using traditional methods (Tan, 2015). In addition, online learning platforms such as Edmodo and Quipper can help students in practicing language skills, acquiring new vocabularies, and improving their understanding on the context of the lesson as well as coping with the limited time available for EFL teaching. (Cakrawati, 2017 and Agustina \& Cahyono, 2017). However, using high technology skill and self-directed learning are needed in learning online. It is such Kuama and Intharaksa's study (2017) inspected that the suitability of online learning for all English language learners points out that low English proficiency students may not be ready for learning English online because they lacked online learning skills and experiences in self-directed learning.

A study regarding online tutoring has been conducted in Hong Kong specified 'star' tutors deliver one-to-one and small-group tutoring with overflow video screens (Bray and Lykins, 2012). It has shown that shadow education has begun to shift into e-learning through the employment of technology on its service. In spite of that, studies taking up the subject of EFL learners' participation in shadow education of English in online setting are scarce. In response to this, the present study sets out to explore the perspective of EFL learners on participation in online shadow education of English, specifically Indonesian learners, as a matter of fact, online shadow education of English in Indonesia keeps rising. Hence, taking the perspective of Indonesian EFL learners participating online shadow education of English is to deal with a more thorough understanding 
on the demands of EFL classroom in Indonesia and uncover the challenges faced by the students learning English in online setting.

\section{METHOD}

Since, this study aims at examining the perspective of Indonesian EFL learners on participation in online shadow education of English, the research design used was survey research. The subjects were EFL learners who experienced the service of English shadow education named KII ( Karya Inspirasi Indonesia ) English course. The data were collected from questionnaire which was developed to elicit learners' response on statements that reflect their participation in online shadow education.

Table 1. Items comprising the research questionnaire

\begin{tabular}{|c|c|c|c|}
\hline Aspect & Indicators & $\begin{array}{l}\text { No. of } \\
\text { items }\end{array}$ & References \\
\hline \multirow{4}{*}{$\begin{array}{l}\text { Reasons: } \\
\text { 1) Further assistance of } \\
\text { learning English }\end{array}$} & & & \multirow{9}{*}{$\begin{array}{l}\text { Alotaibi (2014), } \\
\text { Dwita et al } \\
(2018)\end{array}$} \\
\hline & $\begin{array}{l}\text { Difficulty of learning English } \\
\text { individually }\end{array}$ & 1 & \\
\hline & $\begin{array}{l}\text { Strengthen the weak English } \\
\text { foundation in previous school } \\
\text { years }\end{array}$ & 1 & \\
\hline & Limited learning duration in class & 1 & \\
\hline \multirow{3}{*}{$\begin{array}{l}\text { 2) Inapt classroom } \\
\text { setting }\end{array}$} & Large class & 1 & \\
\hline & $\begin{array}{l}\text { Boring teaching and learning } \\
\text { process }\end{array}$ & 1 & \\
\hline & $\begin{array}{l}\text { Heavy load of homework that is } \\
\text { pointless to the real-life } \\
\text { application }\end{array}$ & 1 & \\
\hline \multirow[t]{2}{*}{$\begin{array}{l}\text { 3) Lack of teachers' } \\
\text { attention }\end{array}$} & $\begin{array}{l}\text { Incomplete discussion on difficult } \\
\text { materials }\end{array}$ & 1 & \\
\hline & $\begin{array}{l}\text { Less learning practices to be } \\
\text { discussed }\end{array}$ & 1 & \\
\hline \multirow[t]{2}{*}{ 4) Social pressure } & Peers having higher competence & 1 & \multirow{3}{*}{$\begin{array}{l}\text { Yung \& Bray } \\
(2017), \text { Dwita et } \\
\text { al (2018), } \\
\text { William (2018) }\end{array}$} \\
\hline & $\begin{array}{l}\text { Peers joining private tutoring } \\
\text { service }\end{array}$ & 1 & \\
\hline 5) Personal desire & $\begin{array}{l}\text { The usefulness of private tutoring } \\
\text { services for their achievement }\end{array}$ & 1 & \\
\hline
\end{tabular}

The questionnaire was developed in closed- and open-ended format. The open-ended questionnaire was arranged in 7 items while the close-ended questionnaire was 10 items. The learners' responses were measured by using a 5-point Likert scale (strongly agree $=1$, strongly disagree $=5$ ). The data was statistically computed to find out the percentage of each statement and then was interpreted descriptively. The data obtained from the open-ended questionnaire were analyzed to elicit the other reasons encompassing EFL learners to participate in online shadow education and challenges that they might have encountered during their learning activity in online setting.

The online questionnaires were distributed through online learning groups. From the distribution, it was obtained 35 respondents. However, not all of those were qualified as the participants of the survey, there were only 28 respondents who have encountered online shadow education of English. 


\section{FINDINGS AND DISCUSSION}

The results of the study were obtained from 35 EFL learners in Indonesia who have experienced online shadow education of English. The distribution of the EFL learners participating in the survey is presented in the following diagram.

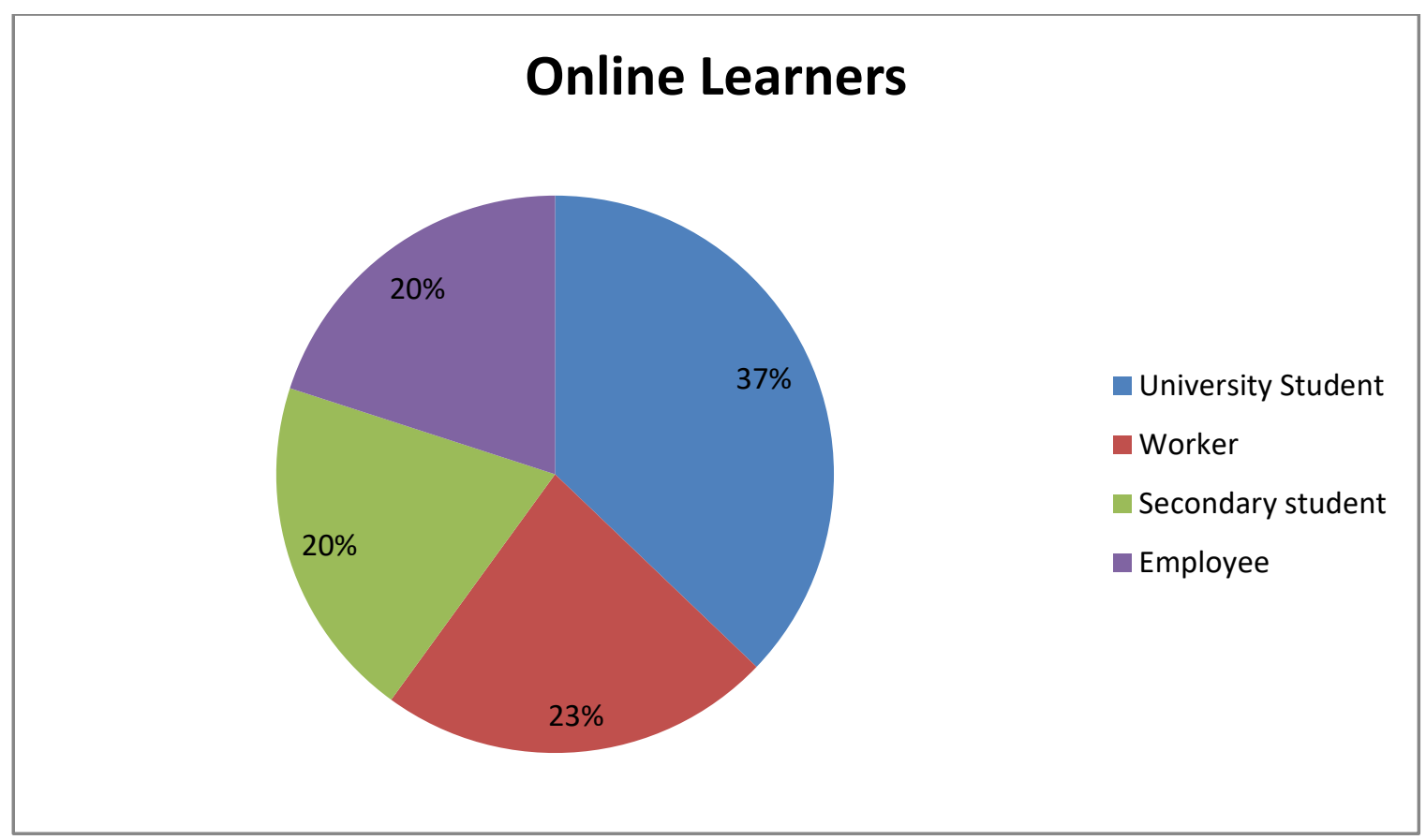

Figure 1. The distribution of EFL learners participating in the survey

There were 35 respondents in total. Most of the respondents were university students with 13 participants. The second dominated respondents were workers with 8 participants. The least respondents were students and employees with 7 participants of each area. In fact, among those 35 respondents, only 28 reported that they had taken an online shadow education of English program.

\section{Reasons Underlying EFL Learners' Participation in Online Shadow Education of English Program}

There were five aspects used to construct the items of the close-ended questionnaire, i.e. further assistance of learning English, inapt classroom setting, lack of teachers' attention, social pressure, and personal desire. In order to answer the first research question on the reasons underlying EFL learners' participation in online shadow education of English, the findings from the close-ended questionnaire are shown in table 2, 3, 4, 5, and 6.

For the first aspect, further assistance of learning English, the data of the findings from the questionnaire are presented in the following table.

Table 2. EFL learners' reasons of participating online shadow education of English 1

\begin{tabular}{lcccc}
\hline \multicolumn{1}{c}{ Questions } & $\begin{array}{c}\text { Strongly } \\
\text { Agree }\end{array}$ & Agree & Neutral & Disagree \\
\hline $\begin{array}{l}\text { Learning English without peers makes English } \\
\text { difficult to understand }\end{array}$ & $33.3 \%$ & $48.7 \%$ & $15.4 \%$ & $2.6 \%$ \\
\hline My low English foundation can be strengthened & $28.2 \%$ & $41 \%$ & $23.1 \%$ & $7.7 \%$ \\
\hline $\begin{array}{l}\text { Time allotment of learning English in the class is } \\
\text { limited }\end{array}$ & $28.2 \%$ & $25.6 \%$ & $10.3 \%$ & $35.9 \%$ \\
\hline
\end{tabular}

Table 2 shows that most respondents $(\mathrm{SA}=33.3 \%$, Agree $=48.7 \%)$ in the study agreed that the presence of peers might help them easier in learning English because they found English difficult to understand if they learned it individually. The learners $(\mathrm{SA}=28.2 \%$, Agree $=41 \%$ ) 
also thought that by participating online shadow education of English, they could strengthen their low English foundation. However, they disagree $(\mathrm{D}=35.9 \%)$ if the limited time allotment of learning English in the class was the reason of their participation in online shadow education of English. It can be concluded that the reason of EFL learners participating in English online shadow education owing to further assistance of learning English covers the presence of peers for learning discussion and the aim to strengthen their low English foundation in previous school years. This finding is consistent with Alotaibi (2014) who found that the difficulty of English language is one of the causes of private tutoring in English.

For the second aspect, inapt classroom setting, the data of the findings from the questionnaire are presented in table 3.

Table 3. EFL learners' reasons of participating online shadow education of English 2

\begin{tabular}{lcccc}
\hline \multicolumn{1}{c}{ Questions } & $\begin{array}{c}\text { Strongly } \\
\text { Agree }\end{array}$ & Agree & Neutral & Disagree \\
\hline The number of students in the class is too big & $38.5 \%$ & $33.3 \%$ & $17.9 \%$ & $10.3 \%$ \\
\hline $\begin{array}{l}\text { The process of teaching and learning in the class } \\
\text { is boring }\end{array}$ & $23.1 \%$ & $38.5 \%$ & $30.8 \%$ & $7.7 \%$ \\
\hline $\begin{array}{l}\text { Many tasks that are pointless in the real-life } \\
\text { application }\end{array}$ & $35.9 \%$ & $46.2 \%$ & $12.8 \%$ & $5.1 \%$ \\
\hline
\end{tabular}

Table 3 shows that $72.2 \%$ respondents agreed and strongly agreed with the statement that the large number of students in the class became the reason they participated in online shadow education of English. Most of the respondents strongly agreed (23.1\%) and agreed (38.5\%) that the process of teaching and learning in the class is boring. Moreover, $82,1 \%$ of the respondents agreed and strongly agreed that most of the tasks given in the class are pointless in the real-life application.

For the third aspect, lack of teachers' attention, the data of the findings from the questionnaire are presented in table 4.

Table 4. EFL learners' reasons of participating online shadow education of English 3

\begin{tabular}{lcccc}
\hline \multicolumn{1}{c}{ Questions } & $\begin{array}{c}\text { Strongly } \\
\text { Agree }\end{array}$ & Agree & Neutral & Disagree \\
\hline $\begin{array}{l}\text { Difficult materials were not completely discussed } \\
\text { in the class. }\end{array}$ & $38.5 \%$ & $38.5 \%$ & $17.9 \%$ & $5.1 \%$ \\
\hline $\begin{array}{l}\text { The amount of practices discussed in the class is } \\
\text { limited }\end{array}$ & $25.6 \%$ & $51.3 \%$ & $17.9 \%$ & $5.1 \%$ \\
\hline
\end{tabular}

Table 4 shows that majority of the respondents (77\%) agreed and strongly agreed with the statement that difficult materials were not completely discussed in the class. Then, similar number of respondents $(76.9 \%)$ were attributed to the next statement that EFL learners agreed and strongly agreed that the amount of practices discussed in the class is limited. Consistent with Dwita et al (2018), the results in tables 3 and 4 show that the inapt classroom setting and lack of teacher's attention are the reasons of EFL learners' participation in shadow education of English.

For the fourth aspect, social pressure, the data of the findings from the questionnaire are presented in table 5 .

Table 5. EFL learners' reasons of participating online shadow education of English 4

\begin{tabular}{lcccc}
\hline \multicolumn{1}{c}{ Questions } & $\begin{array}{c}\text { Strongly } \\
\text { Agree }\end{array}$ & Agree & Neutral & Disagree \\
\hline $\begin{array}{l}\text { My partners' English competence is better than } \\
\text { me }\end{array}$ & $25.6 \%$ & $33.3 \%$ & $33.3 \%$ & $7.7 \%$ \\
\hline $\begin{array}{l}\text { Most of my partners joined online shadow } \\
\text { education of English }\end{array}$ & $2.6 \%$ & $20.5 \%$ & $51.3 \%$ & $25.6 \%$ \\
\hline
\end{tabular}


Table 5 shows that the learners $(58.9 \%)$ thought their partners' English competence is better than theirs. However, $51.3 \%$ of respondents neither agree nor disagree to the statement that most of their partners joined online shadow education of English. This result indicates that social pressure that underlie EFL learners' participation in online shadow education of English is not about going with the stream but rather onto the anxiety of the level of English competence the learners acknowledge.

For the fifth aspect, personal desire, the data of the findings from the questionnaire are presented in table 6.

Table 6. EFL learners' reasons of participating online shadow education of English 5

\begin{tabular}{lcccc}
\hline \multicolumn{1}{c}{ Questions } & $\begin{array}{c}\text { Strongly } \\
\text { Agree }\end{array}$ & Agree & Neutral & Disagree \\
\hline $\begin{array}{l}\text { I want to develop my English competence more } \\
\text { than just a score I have attained in the previous } \\
\text { school years. }\end{array}$ & $74.4 \%$ & $25.6 \%$ & $0 \%$ & $0 \%$ \\
\hline
\end{tabular}

Table 6 shows that the whole respondents $(\mathrm{SA}=74.4 \%, \mathrm{~A}=25.6 \%)$ agreed and strongly agreed that they wanted to develop their English competence more than just a score they have attained in the previous school years. It revealed that the learners believed the usefulness of private tutoring services contributes to their achievement. This is in accordance with the study by William (2018) claiming that students registering private tutoring services due to their view of the usefulness. Through these results, it was distinctly shown that five aspects (further assistance of learning English, inapt classroom setting, lack of teachers' attention, social pressure, and personal desire) encompassing the reasons of EFL learners joining a shadow education of English in online setting are the same with the conventional one.

Furthermore, the findings obtained from the open-ended questionnaire showed the responses rendered mostly lied on the practicality. The majority of the respondents stated that online shadow education of English is more flexible and less expensive compared to general education. The learners added that they could learn English everywhere and anytime that made them easy to join the class without worrying of being left by their peers on the lessons discussed and they could have in well spent time on their leisure time Then, it was revealed that some of the learners admitted that they felt uncomfortable to learning English in the class-when their peers are smarter. The last, the learning materials were also considered more interesting due to the use of audio-visual presentation (videos) and the use of various learning sources that caused them more excited in learning English. These findings clearly signify that EFL learners' participation in online shadow education of English is not only generated by the similar reasons with the conventional shadow education of English but it also lies on the practicality of joining the program and the attractiveness of the learning material.

\section{Challenges Faced by the Students Learning English in Online Setting}

The data obtained from the open-ended questionnaire eliciting the challenges faced by the students learning English in online setting showed that mostly the obstacles lie on the technical issues. The most mentioned problem was related to the condition of internet connection. The respondents mentioned bad internet connection hindered the learning activity; It interrupted the communication between the learners and the tutors and they felt the situation made the learning activity become less interactive as well. There was also a mention on the inability of the learners in understanding the linguistic component because of the limited interaction between the learners and the tutors. In addition, some of the respondents also stated that the application used as the learning platform of the shadow education they joined was not effective, however; they didn't specifically mention the name of the application.

Despite the technical issues, the findings also revealed that self-regulation took a part as the rise of the obstacles in online language learning. Most respondents admitted that they become 
lazy and lack of discipline as well as less motivation due to the absence of teacher's supervision. This is in line with Hromalik \& Koszalka's (2018) study that denotes language learners struggled to remain motivated throughout the online language learning course. Apart from that, the respondents said that they feel difficult to manage the time. They tend to be out of focus when joining the online learning the distraction of other fun activities they could do that were not related to their learning activity.

Apparently, the challenges found from this survey concerned with teaching pedagogy,they are; some of difficult materials were not solved effectively,the teaching technique that was boring- The teachers' way of delivering the materials and the activities were monotonous.

\section{CONCLUSIONS}

As technology is made to ease human life, online language learning is one of the worthwhile applications of the technology that has been benefited from the advancement of technology which is meant to deliver an extended learning for language learner. Let alone online shadow education of English, it is viewed as an alternative to provide a learning experience that touches the practicality to facilitate EFL learning. EFL learners considered shadow education of English in online setting allow them to have more flexibility in learning and it is more economical than the conventional one. Nevertheless, the five aspects of EFL learners' reasons in participating online shadow education of English including further assistance of learning English, inapt classroom setting, lack of teachers' attention, social pressure, and personal desire appear the same with the conventional one. Therefore, instead of choosing the conventional shadow education of English to assist their language learning, they choose the online learning due to its additional benefit, that is practicality.

Regardless of the practicality, it was found that technical issues such as bad internet connection and limited interaction between the tutor and the learner became the major case in online shadow education of English. Moreover, EFL learners also admitted that they suffer from self-regulation learning strategy and it relates to teaching pedagogy as well. The result of this study implies what Hromalik \& Koszalka (2018) have conveyed that given the inherent physical and temporal distance between the instructor and the students, the need for engaging and effective learning resources in online language environment is crucial.

Methodologically, this research has attempted to undertake the perspective of EFL learners on shadow education of English in online setting. As with all studies, issues with limitations, validity, and reliability are commonplace. It can be suggested that EFL practitioners and education stakeholders should understand the perspective of EFL learners on shadow education of English in online setting in order to design effective syllabuses, language program, and teaching methods as well as establishing educational policies. The findings can be the basis of further quantitative analysis such as exploring the correlation among the reasons, challenges, and teaching effectiveness in online language learning.

\section{REFERENCES}

Agustina, E., \& Cahyono, B. Y. (2017). Perceptions of Indonesian teachers and students on the use of quipper school as an online platform for extended EFL learning. Journal of Language Teaching and Research, 8(4), 794-800.

Alotaibi, G. N. (2014). Causes of private tutoring in English: perspective of Saudi secondary school students and their parents. Studies in Literature and Language, 8(3), 79-83.

Bray, M. (2014). The impact of shadow education on student academic achievement: why the research is inconclusive and what can be done about it. Asia Pacific Educ. Rev, 15, 381389.

Bray, M., \& Lykins, C. (2012). Shadow education: private supplementary tutoring and its implications for policy makers in Asia. Mandaluyong City, Philippines: Asian Development Bank and Hong Kong: Comparative Education Research Centre, The 
University of Hong Kong.

Bray, M., \& Silova, I. (2006). The private tutoring phenomenon: International patterns and perspectives (I. Silova, V. Budiene \& M. Bray, Eds.). Education in a Hidden Market Place: Monitoring of Private Tutoring (pp. 27-40). New York: Open Society Institute.

Cakrawati, L. M. (2017). Students' perceptions on the use of online learning platforms in EFL classroom. English Language Teaching and Technology Journal, 1(1), 22-30.

Chan, V. N. M. (2019). English private tutoring in Macao: perceptions of senior secondary three students. ECNU Review of Education, 2(1), 44-63,

Dwita, S., Cheisviyanny, C., Helmy, H., \& Marwan. (2018). Factors comprising motivation to participate in shadow education in West Sumatra. Advances in Economics, Business and Management Research, 57, 550-558.

Hromalik, C.D., \& Koszalka, T.A. (2018). Self-regulation of the use of digital resources in an online language learning course improves learning outcomes. Distance Education, 1-21

Khan, I. A. (2016). Effectiveness of e-learning for the teaching of English: a study of comparative strategies. Advances in Language and Literary Studies, 7(3), 125-135.

Kuama, S., \& Intharaksa, U (2016). Is online learning suitable for all English language students. PASAA: A Journal of Language Teaching and Learning, 52, 61-90.

Mahmud, R., \& Kenayathulla, H. B., (2017). Shadow education: patterns and scale of private supplementary tutoring in English in secondary education at urban Dhaka in Bangladesh. Social Science Information, 1-18.

Nam, Y., \& Chan, K. (2019). The roles of mainstream schooling and shadow education in English language teaching: a case study in Hong Kong. Educational Journal, 8(1), 16-26.

Shopova, T. (2014). Digital literacy of students and its improvement at the university", Journal on Efficiency and Responsibility in Education and Science, 7(2), 26-32.

Tan, P. J. B. (2015). English e-learning in the virtual classroom and the factors that influence ESL (English as a Second Language): Taiwanese citizens' acceptance and use of the modular object-oriented dynamic learning environment. Compare: A Journal of Comparative and International Education, 1-15.

William, S. (2018). Students' perspective on buying private tuition services. International Journal of Research Studies in Education, 7(2), 105-119.

Wang, D., \& Bray, M. (2016). When whole-person development encounters social stratification: teachers' ambivalent attitudes towards private supplementary tutoring in Hong Kong. The Asia-Pacific Education Researcher, 25(5-6), 873-881.

Yung, K. W. H., \& Bray, M. (2017). Shadow education: features, expansion and implications. In T. K. C. Tse \& M. Lee (Eds.), Making sense of education in post-handover Hong Kong: Achievements and challenges (pp. 95-111). London: Routledge. 